\title{
FORMS AND AVAILABILITY OF SOIL PHOSPHORUS IN TEMPERATE FORESTS IN SOUTHERN CHILE AND FLANDERS
}

\author{
FORMAS Y DISPONIBILIDAD DE FOSFORO EN EL SUELO DE BOSQUES \\ TEMPLADOS EN EL SUR DE CHILE Y FLANDERS
}

\author{
Katleen De Brouwere ${ }^{1}$, Ann Thijs ${ }^{1}$, Maarten Hens ${ }^{2}$ \& Roel Merckx ${ }^{1}$
}

\begin{abstract}
This study investigated the different forms and availability of $\mathrm{P}$ in soil profiles from temperate forests in southern Chile (two sites: Nothofagus obliqua (Mirb.) Bl. and Nothofagus betuloides (Mirb.) Oerst.) and Flanders, Belgium (two sites: Pinus nigra Arnold and Betula pendula Roth). Soils were sampled according to genetic horizonation and analysed for organic matter, oxalateextractable $\mathrm{P}, \mathrm{Al}$ and $\mathrm{Fe}$, total inorganic $\mathrm{P}$ and total organic P. Phosphorus availability was assessed using an isotopic exchange technique and anion exchange membranes. The total $\mathrm{P}$ content was higher for the Chilean andosols and remained relatively high in the whole soil profile (1413-187 mg $\mathrm{P} \mathrm{kg}^{-1}$ ) whereas total $\mathrm{P}$ decreased sharply in the lower horizons of the Flemish podzols (575$\left.4 \mathrm{mg} \mathrm{P} \mathrm{kg}{ }^{-1}\right)$. There was a strong predominance of organic $\mathrm{P}$ in the Chilean soils (up to $90 \%$ of total P). The high volcanic activity in Chile is responsible for the large amounts of allophone, which entail high P-fixing capacities in these soils. Notwithstanding the much larger total P content in Chilean andosols compared to the Flemish podzols, both soil types feature comparable amounts of available P (AEM-P). The two phosphorus availability indices (IEP and AEM-P) correlated rather well for the Flemish forest sites $\left(R^{2}=0.67\right)$, while the same correlation was lacking for the Chilean soil profiles $\left(R^{2}=\right.$ 0.11). However, a strong relation between AEM-P and the organic matter content of the andosols emerged. The presence of $\mathrm{Al}$ and DOC in the AEM-extracts of eight selected Chilean soil samples suggests the extraction of organo-mineral colloids by the membrane. The lack of
\end{abstract}

${ }^{1}$ Laboratory for Soil and Water Management, Katholieke Universiteit Leuven, Kasteelpark Arenberg 20, B-3001 Heverlee, Belgium.

${ }^{2}$ CSIRO, Plant Industry, GPO Box 1600, Canberra Act 2601, Australia.

Email: Katleen.debrouwere@agr.kuleuven.ac.be correlation between AEM-P and IEP for the Chilean soils may be related to the presence of these colloids, as they may lead to an overestimation of IEP as well as biased AEM-P values. Differences in forms and availability of phosphorus between the Chilean and the Flemish soil profiles were mostly ascribed to differences in soil properties rather than to differences in anthropogenic influences.

KEYwords: Andosols, phosphorus availability, podzols

\section{RESUMEN}

Este estudio investiga las diferentes formas y disponibilidad de $\mathrm{P}$ en perfiles de suelo en bosques templados del sur de Chile (2 sitios: Nothofagus obliqua (Mirb) Blume y Nothofagus betuloides (Mirb.) Oerst) y Flanders, Bélgica (2 sitios: Pinus nigra Arnold y Betula pendula Roth). Los suelos fueron muestreados de acuerdo con los horizontes genéticos y analizados para materia orgánica, $\mathrm{P}$ oxalato-extraíble, $\mathrm{Al}$ y $\mathrm{Fe}, \mathrm{P}$ inorgánico total y $\mathrm{P}$ orgánico total. La disponibilidad de fósforo fue evaluada utilizando una técnica de intercambio isotópico y membranas de intercambio aniónico. El contenido total de $\mathrm{P}$ fue más alto para los suelos andosoles en Chile y relativamente alto en el perfil completo del suelo (1413$187 \mathrm{mg} \mathrm{P} \mathrm{kg}^{-1}$ ), mientras que el $\mathrm{P}$ total decreció pronunciadamente en los horizontes más bajos de los suelos podzoles de Flanders (575-4 $\mathrm{mg} \mathrm{P} \mathrm{kg}^{-1}$ ). Hubo una clara predominancia de $\mathrm{P}$ orgánico en los suelos chilenos (> 90\% de P total). La alta actividad volcánica en Chile es responsable por las grandes cantidades de alofan, lo cual se traduce en una alta capacidad de fijación de fósforo en estos suelos. A pesar de los mayores contenidos de $\mathrm{P}$ total en los andisoles de Chile comparado con los podzoles de Flanders, ambos tipos de suelo presentan cantidades comparables de $\mathrm{P}$ disponible ( $\mathrm{P}$ AEM). Los índices de disponibilidad de los dos tipos de fósforo (IEP y AEM-P) tuvieron buena correlación para los sitios en Flanders $\left(R^{2}=0.67\right)$, mientras que la correlación fue pobre para los suelos en Chile $\left(R^{2}=0.11\right)$. 
Gayana Bot. 60(1), 2003

Sin embargo, se obtuvo una fuerte relación entre AEM$\mathrm{P}$ y el contenido de materia orgánica en los andosoles. La presencia de Al y DOC en los extractos-AEM de ocho muestras seleccionadas de los suelos en Chile sugiere la extracción de coloides organo-minerales por la membrana. La falta de correlación entre AEM-P y IEP para los suelos en Chile puede estar relacionada a la presencia de estos coloides, y éstos pueden llevar a una sobrestimación de IEP, así como valores sesgados de AEM-P. Las diferencias en las formas y disponibilidad de fósforo entre los perfiles de suelo en Chile y Flanders, pueden ser explicadas por las diferencias en las propiedades de los suelos más que por la influencia antrópica.

Palabras Claves: Andosoles, disponibilidad de fósforo, podzoles.

\section{INTRODUCTION}

Nitrogen and phosphorus are thought to be the key elements in limiting primary productivity in temperate forests (Attiwell \& Adams 1993). Our un- derstanding of the role of $\mathrm{P}$ in the functioning of forest ecosystems is however severely hampered by difficulties in identifying and quantifying available $P$ fractions in forest soils. Phosphorus forms in soil cover a wide range of forms (Fig. 1) and include both organic and inorganic forms (Tiessen et al. 1984). These forms can be either rapidly or slowly cycling. The central P pool is the soil solution pool, which is immediately available for plants and is in equilibrium with other $P$ pools. In this study, we compare the different fractions and availability of phosphorus in two widely differing forest soils of Chile and Flanders, respectively andosols and podzols. Most studies on which our current understanding of soil nutrient cycling in temperate forests are based, have been conducted in forests disturbed by direct human action and/or by airborne chemicals of anthropogenic influence. The comparison of undisturbed Chilean temperate forests and highly disturbed European forests would possibly lead to a greater understanding of how these distortions affect $\mathrm{P}$ cycling.

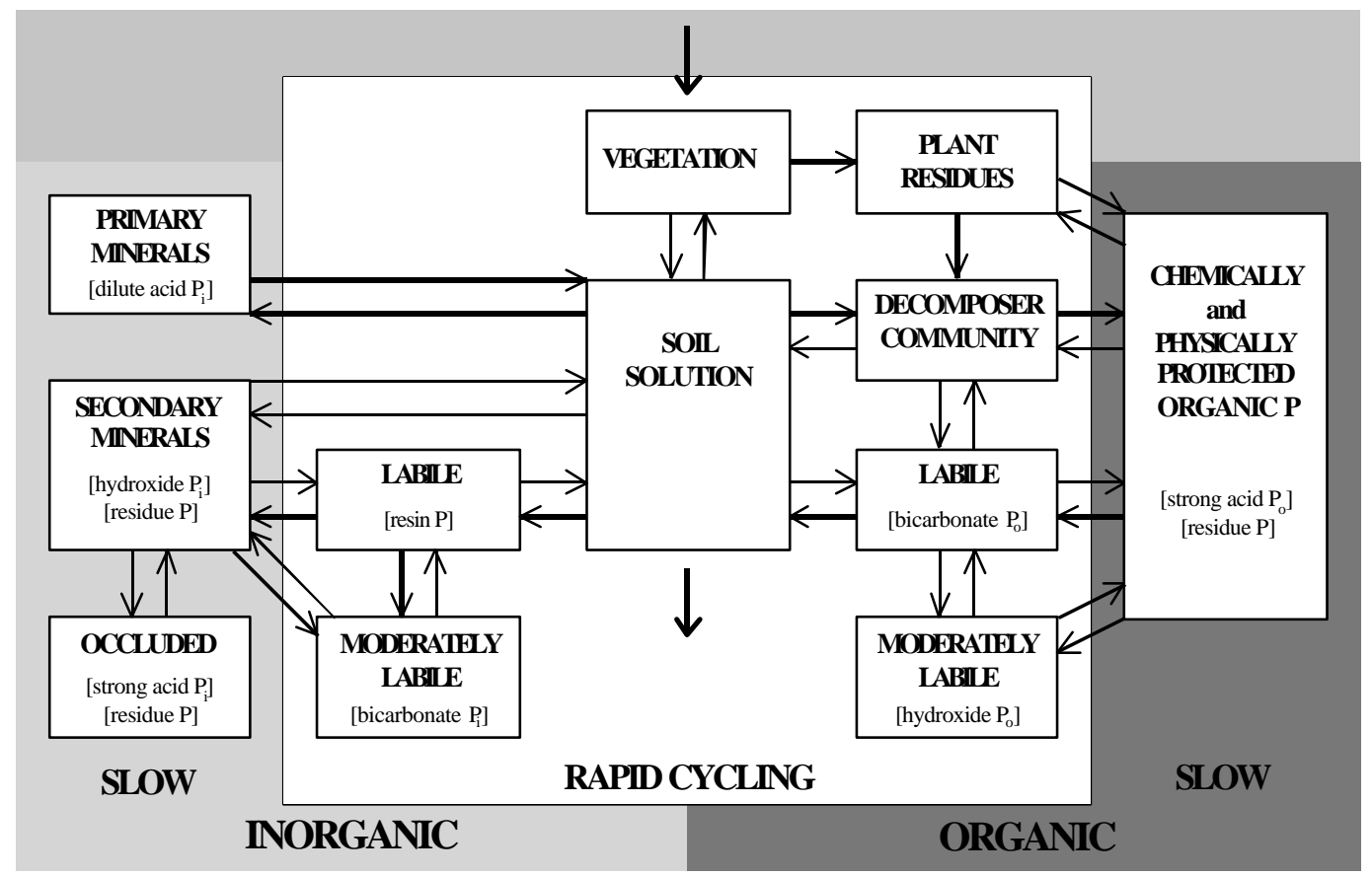

FIGURE 1: Schematic overview of different phosphorus pools in soils (Tiessen et al. 1984). 
Here we compare forms and availability of phosphorus in Chilean and Flemish forest soils, and attempt to explain differences. As the distribution of phosphorus over different $\mathrm{P}$ pools (Fig. 1) is strongly influenced by soil properties, we also characterised physical and chemical attributes of soils at our sites. Andosols are characterized by a high phosphate retention capacity due to the presence of allophanes, imogolite, $\mathrm{Al}$ and $\mathrm{Fe}$ (oxy)hydroxides and $\mathrm{Al}$ and $\mathrm{Fe}$ humus complexes (Driessen \& Dudal 1991). P sorption on inorganic surfaces includes: (i) ligand exchange of aluminium oxides and -hydroxides (McLaughlin et al. 1981), as well as of surface-bound silicate and bisulphate (Rajan \& Fox 1975) and (ii) precipitation of Al phosphates. Andosols contain relatively large fractions of organic matter, which play an ambiguous role for P sorption: (i) organic matter counteracts $\mathrm{P}$ sorption by blocking $\mathrm{P}$ sorption sites and by competition between $\mathrm{P}$ and organic anions for sorption sites (Mora \& Canales 1995), (ii) organic matter stimulates $P$ sorption by stabilizing $\mathrm{Al} / \mathrm{Fe}$ surfaces and organic matter promotes formation of new anion sorption sites (Kwong \& Huang 1979). Generally, podzols have a much smaller $P$ retention capacity due to the much less abundance of above mentioned components in these soils. However, the presence of organo-metallic compounds are key features in both soils and comparing $\mathrm{P}$ behaviour in both soils may provoke insight in the role of the type of these organo-metallic compounds for $\mathrm{P}$ sorption and $\mathrm{P}$ availability.

\section{MATERIALS AND METHODS}

Soil profiles were sampled at two pristine Chilean forest sites and at two Flemish forest sites. One of the Chilean forests is situated in the Central Valley (Paillaco) and the main tree species there is $\mathrm{No}$ thofagus obliqua (Mirb) Bl. The other Chilean study area is located in Puyehue National Park and main tree species there is Nothofagus betuloides (Mirb.) Oestr. The two Flemish forest sites (Hoogmoerheide A: Pinus nigra Arnold and Hoogmoerheide B: Betula pendula Roth) are both situated at the Hoogmoerheide in Merksplas. The Chilean soils are Andosols and the Flemish soils are podzols. At each site, two profile pits were sampled with $5 \mathrm{~cm}$ intervals up to $80 \mathrm{~cm}$ depth for the Flemish soil profiles and $40 \mathrm{~cm}$ depth for the Chilean soil profiles. For the latter soil profiles, below this $40 \mathrm{~cm}$ soil layer, B $(40-75 \mathrm{~cm})$ and C horizon $(75-130 \mathrm{~cm})$ soil samples were taken. All soils were air-dried and sieved $(2 \mathrm{~mm})$ prior to analysis.

Organic matter content was determined as \% loss in weight on ignition (\% LOI) at $550^{\circ} \mathrm{C}$. Ignited and unignited soils were extracted with 0.5 $\mathrm{M} \mathrm{H}_{2} \mathrm{SO}_{4}$ for $16 \mathrm{~h}$. In these $0.5 \mathrm{M} \mathrm{H}_{2} \mathrm{SO}_{4}$ extracts, molybdate reactive phosphorus (MRP) was measured colorimetrically. Total P content (TP) and total inorganic $\mathrm{P}$ content (TIP) are based on MRP in these extracts of the ignited and unignited soils, respectively. Total organic P content (TOP) is defined as the difference between TP and TIP.

Oxalate-extractable Al, Fe and $\mathrm{P}$ content was determined following the Schwertmann method (Schwertmann 1973). The Al, Fe and P-content in the extracts was measured with Inductive Coupled Plasma analysis (ICP-OES, Perkin Elmer).

For the determination of isotopicallyexchangeable $\mathrm{P}$ (IEP), about $1.5 \mathrm{~g}$ soil was shaken in $30 \mathrm{ml} \mathrm{H} \mathrm{H}_{2} \mathrm{O} \mathrm{DD}$ for $16 \mathrm{~h}$, then carrier free ${ }^{32} \mathrm{P}$ (half life 14.3 days) was added to the suspension. After $24 \mathrm{~h}$ of end-over-end shaking, the suspension was centrifuged and filtered $(0.22 \mu \mathrm{m})$. MRP was measured in the filtrate and ${ }^{32} \mathrm{P}$-activity determined with liquid scintillation. The amount of IEP was defined as:

$$
\operatorname{IEP}\left(\mathrm{mg} \mathrm{P} \mathrm{kg}^{-1}\right)=\frac{C_{31} \mathrm{PO}_{4} \text {,solution }}{C_{{ }^{32} \mathrm{PO}_{4} \text {,solution }}} \frac{R}{M}
$$

where $\mathrm{R}$ is the total ${ }^{32} \mathrm{PO}_{4}$ activity $(\mathrm{Bq})$ introduced into the soil suspension at $\mathrm{t}=0$.

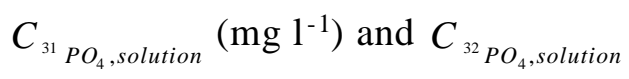

$\left(\mathrm{Bq}^{-1}\right)$ are respectively the concentrations of ${ }^{31} \mathrm{PO}_{4}$ and ${ }^{32} \mathrm{PO}_{4}$ in solution. $\mathrm{M}$ is the mass of the soil (kg). $\mathrm{pH}$ of these suspensions was also measured.

For determination of the AEM-P content, 2 anion exchange membranes (Product 55164 2S; BDH Laboratory Supplies, Poole, England) were shaken in a soil-water suspension for $16 \mathrm{~h}$. P was then desorbed from the resins in a $0.5 \mathrm{M} \mathrm{HCl}$ extraction (2 h). MRP was determined in the AEM$\mathrm{P}$ extract. In 12 selected samples the content of $\mathrm{Al}$ 
Gayana Bot. 60(1), 2003

and dissolved organic carbon (DOC) in these resin extracts was measured.

\section{RESULTS}

The organic matter content was rather high throughout the entire Chilean soil profiles. At Paillaco, \% LOI decreases from $53 \%$ to $17 \%$ at $75 \mathrm{~cm}$ below soil surface. For the Flemish soil profiles, e.g. at Hoogmoerheide A, \% LOI was $64 \%$ at the upper layer, but decreased below $3 \%$ from $13 \mathrm{~cm}$ below the surface (except $17 \%$ LOI at 22-25 cm depth).

The $\mathrm{pH}$ of the soil at Hoogmoerheide ranged between 3.7 and 4.6, whereas $\mathrm{pH}$ at in the Chilean soils ranged between 5.5 and 6.4 .

In the Chilean soil profiles TP decreased gradually from 1,413 to $451 \mathrm{mg} \mathrm{TP} \mathrm{kg}^{-1}$ in lower horizons at Paillaco and from 700 to $190 \mathrm{mg} \mathrm{TP} \mathrm{kg}^{-1}$ at Puyehue. Organic $\mathrm{P}$ accounted on average for $73 \%$ of TP (minimum $49 \%$ and maximum $90 \%$ ). In the Flemish soil profiles TP is lower than in the Chilean soils; at Hoogmoerheide A TP decreased from $550 \mathrm{mg} \mathrm{P} \mathrm{kg}^{-1}$ in the upper layer to $22 \mathrm{mg} \mathrm{P} \mathrm{kg}^{-1}$ at $70 \mathrm{~cm}$ below soil surface. The percentage TOP/TP ranged from 7 to 81 $\%$ in the Flemish soil profiles. In Fig. 2, a Chilean (Paillaco) and a Flemish (Hoogmoerheide A) profile with respect to TP is shown.

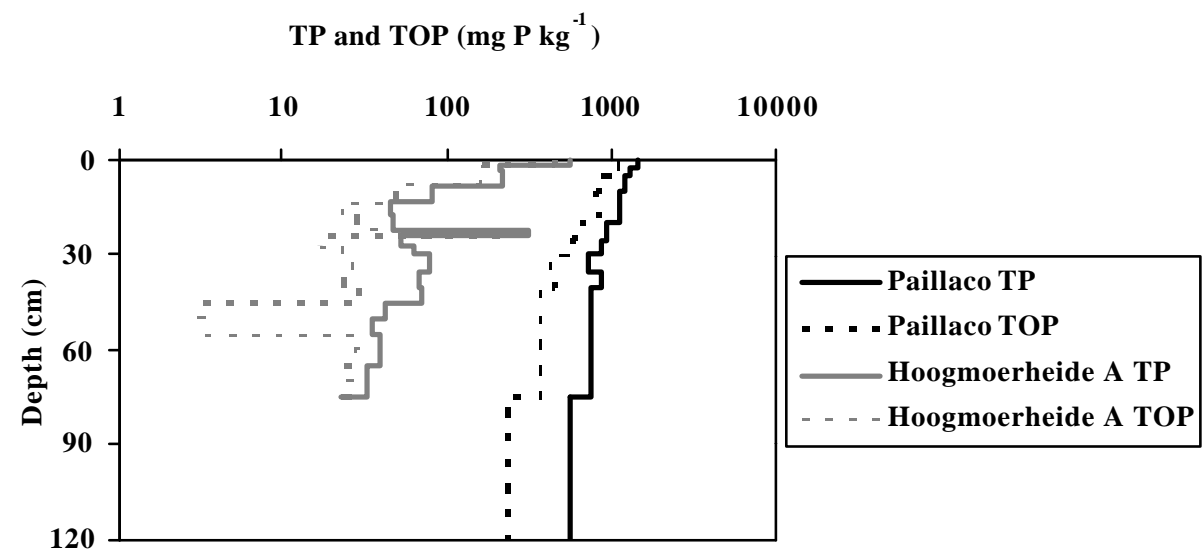

FIgure 2: Phosphorus contents (TP and TOP) of soil profiles at Paillaco (Chile) and Hoogmoerheide A (Flanders). The $\mathrm{X}$-axis is expressed on a logarithmic scale.

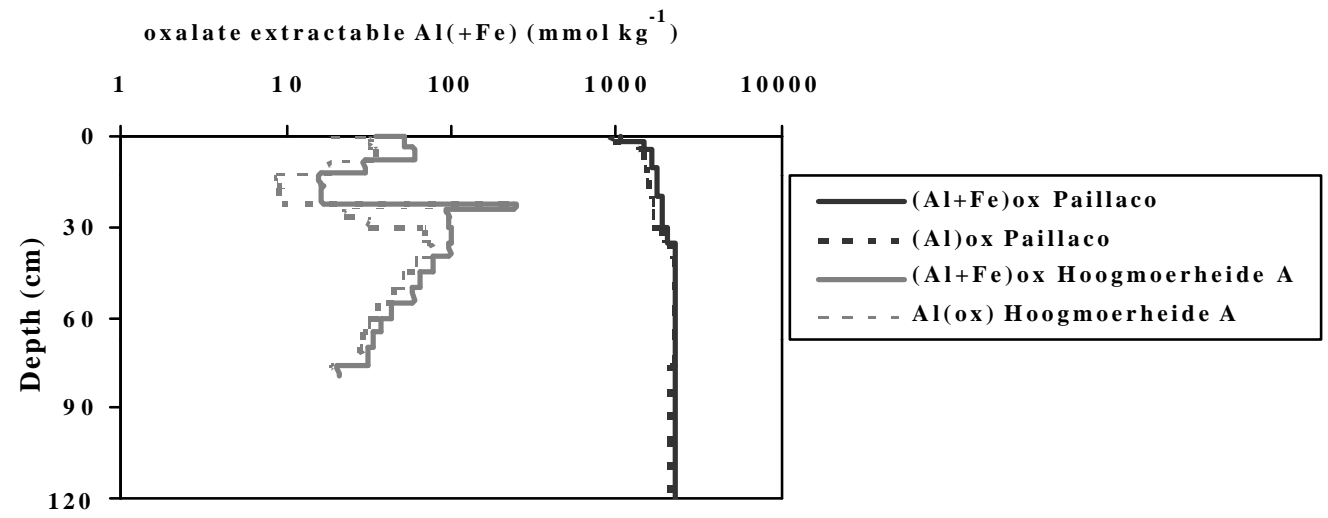

Figure 3: Oxalate extractable Fe and $\mathrm{Al}$ content of soil profiles at Paillaco (Chile) and Hoogmoerheide A (Flanders). The $\mathrm{X}$-axis is expressed on a logarithmic scale. 
At Paillaco the Al concentration ranged from 953 to $2224 \mathrm{mmol} \mathrm{kg} \mathrm{kg}^{-1}$ and the Fe concentration ranged from 131 to $211 \mathrm{mmol} \mathrm{Fe} \mathrm{kg}^{-1}$ (Fig. 3). At Puyehue the Al concentration is a 5 fold lower (187 to $870 \mathrm{mmol} \mathrm{kg}^{-1}$ ) than at Paillaco. The Fe-content (71 to $181 \mathrm{mmol} \mathrm{Fe} \mathrm{kg}^{-1}$ ) is comparable to that of Paillaco. The Flemish soils contained much less oxalate extractable Fe and Al than the Chilean soils resulting in a lower sorption capacity for $\mathrm{P}$. For example, at Hoogmoerheide A the upper layer contains $19 \mathrm{mmol} \mathrm{Al} \mathrm{kg}^{-1}$, and under a sharp peak in $\mathrm{Al}$ at $22 \mathrm{~cm}$ soil depth $\left(216 \mathrm{mmol} \mathrm{Al} \mathrm{kg}^{-1}\right) \mathrm{Al}$ levels off to $19 \mathrm{mmol} \mathrm{Al} \mathrm{kg}^{-1}$. The Fe profile is comparable to the Al profile with a peak at 25 $\mathrm{cm}$ depth followed by a decrease to $7 \mathrm{mmol} \mathrm{Fe}$ $\mathrm{kg}^{-1}$.

At Paillaco the availability of P measured as AEM-P decreased gradually from 26 to $<0.1 \mathrm{mg}$ AEM-P kg ${ }^{-1}$. At Hoogmoerheide A AEM-P decreased from 44 to $<0.1 \mathrm{mg}$ AEM-P kg ${ }^{-1}$ (Fig. 4).

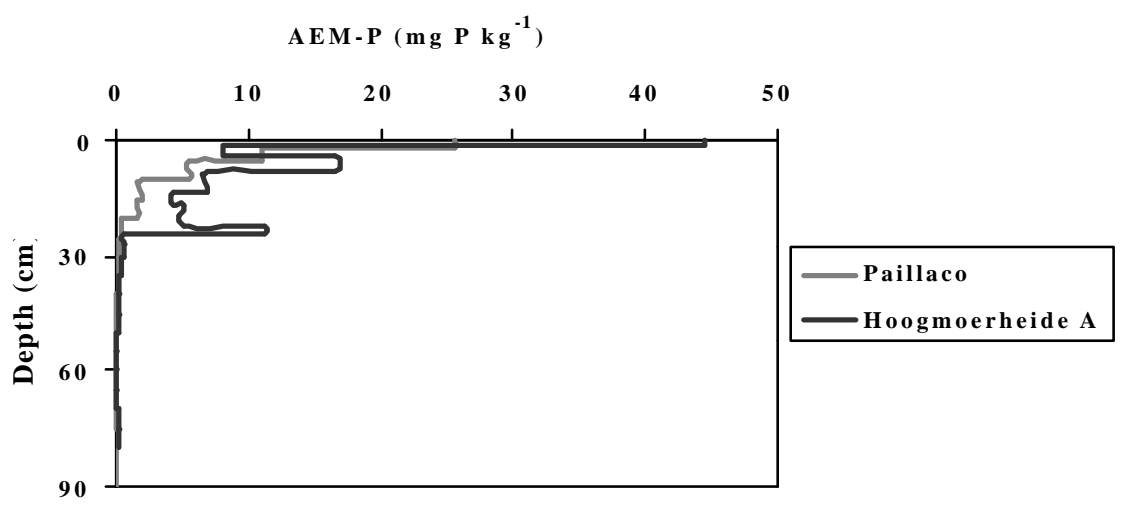

FIgURE 4: Anion exchange membrane extractable P content of soil profiles at Paillaco (Chile) and at Hoogmoerheide (Flanders).

Values for IEP range from $<1$ to $86 \mathrm{mg} \mathrm{P} \mathrm{kg}^{-1}$ in Flemish the soils and from 11 to $>9,000$ in the Chilean soil profiles. Some IEP-values for Chilean soils have unrealistic values since theoretically IEP cannot exceed total $\mathrm{P}$ content. These unrealistic values resulted from analytical problems both in determining ${ }^{31} \mathrm{P}$ concentration in solution because of detection limit $\left(0.01 \mathrm{mg} \mathrm{P}^{-1}\right)$ and in determin- ing ${ }^{32} \mathrm{P}$ at reasonable ${ }^{32} \mathrm{P}$ spike doses.

The two phosphorus availability indices (IEP and AEM-P) correlated rather well for the Flemish forest sites $\left(R^{2}=0.67\right)$, while the same correlation was lacking for the Chilean soil profiles $\left(R^{2}=0.11\right)$. There was however a strong relation between AEM$\mathrm{P}$ and the organic matter content of the Chilean soils (Fig. 5).

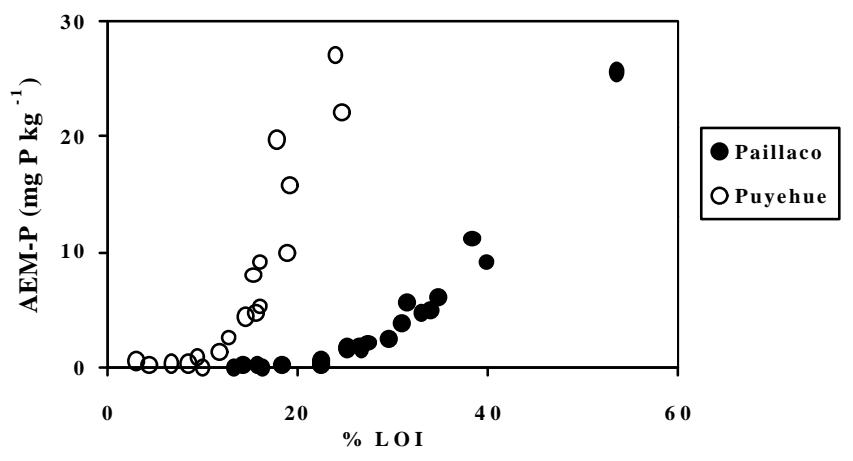

FIGURE 5: Relationship between AEM-P and organic matter content (\% LOI) for Chilean soils at Paillaco and at Puyehue. 


\section{DISCUSSION}

The high content of organic matter (OM) throughout the Chilean profiles can be explained by the presence of allophanes. It is believed that this amorphous Al clay mineral hinders the decomposition of $\mathrm{OM}$ in soils, either by formation of stable humus-clay or by controlling the decomposition of OM by micro-organisms (toxicity of $\left.\mathrm{Al}^{3+}\right)$ (Kosaka etal. 1962). In the Flemish soil profiles (Hoogmoerheide A) the podzolization process can clearly be seen. Chilluviation and cheluviation result in a spodic horizon underlying an albic horizon. The spodic horizon $(22-25 \mathrm{~cm})$ features larger amounts of $\mathrm{OM}$, $\mathrm{Al}$ and $\mathrm{Fe}$ than the overlying albic horizon. Aran et al. (2001) compared the role of organo-metallic complexes in soil formation processes in both a podzol and a andosol. They concluded that in an andosol, high stability of organo-metallic associations against dissaggregation, dispersion and mineralization, inhibits clay illuviation and transport of other solubles through the profile. They stated that these conditions lead to the striking accumulation of organic carbon observed in andosols, which also revealed in our data. According to Aran et al (2001), the physically stable organo-metallic complexes in podzols are more affected by biodegradation and hence lead to al lower organic matter accumulation. However, in the latter soils, organo-metallic complexes accumulate after mobilization and insolubilization processes occurring in the spodic horizon.

The large percentage of TOP in TP of andosols is reported by other authors (Bishop et al. 1994; Cajuste et al. 1995; Otani \& Ae 1999).

Despite the large difference in TP between the Chilean and Flemish soils, AEM-P values are comparable for both soil types. This can easily be explained by the notoriously high P-fixing capacity of andosols due to the large amounts of allophanes and the smaller P-fixing capacity of podzols.

A strong relationship between AEM-P and the organic matter content of the Chilean soils was observed (Fig.5). This phenomenon may be explained by colloidal forms of phosphorus that may be present in andosols as suggested by Negrin etal. (1995). The presence of $\mathrm{Al}\left(0.5-2.2 \mathrm{mg} \mathrm{l}^{-1}\right)$ and DOC (40-105 $\left.\mathrm{mg} \mathrm{l}^{-1}\right)$ in the resin-extracts seems to confirm the existence of these compounds in the Chilean andosols. These organomineral complexes are probably hydrolyzed during the colorimetric measurement of ortho-P in the $0.22 \mu \mathrm{m}$ extract during the assessment of IEP and in the $\mathrm{HCl}$ extract during the determination of AEM-P. In this way the colloids can account for the overestimation of IEP (Hens 1999) and also for a bias in AEM-P (Hernandez-Moreno \& Negrin 1998). Whether these colloidal P-forms contribute to the pool of plantavailable $\mathrm{P}$ is not yet known and should be investigated.

In conclusion we can state that the differences in $\mathrm{P}$ forms and $\mathrm{P}$ availability between the Chilean and the Flemish soils can largely be ascribed to the differences in the soil matrix. The high volcanic activity in Chile is responsible for the large amounts of allophanes, which entail high P-fixing capacities in these soils. Phosphorus availability parameters that are well understood for podzols are more complex to interpret for Chilean andosols due to the predominance of organic forms of $\mathrm{P}$.

\section{ACKNOWLEDGMENTS}

This study was part of the Bilateral Project ChileFlanders BIL 99-4, supported by the Ministry of The Flemish Community

\section{REFERENCES}

Attiwell, P.M., \& M.A. Adams. 1993. Nutrient cycling in forests. New Phytologist 124: 561-582.

Aran, D., M. Gury \& E. Jeanroy. 2001. Organo-metallic complexes in an Andosol: a comparative study with a Cambisol and Podzol. Geoderma 99: 6579.

Bishop, M.L., A.C.Chang \& R.W.K. Lee. 1994. Enzymatic mineralization of organic phosphorus in a volcanic soil in Chile. Soil Science 157: 238-243.

Cajuste, L.J., L. Cruz-díaz, R.J. Laird, R. CarrilloGonzález, G. Palomino \& L. Cajuste. 1995. Phosphorus availability in volcanic ash soils. Arid Soil Research and Rehabilitation 9: 271-277.

Driessen, P.M. \& R. Dudal. 1991. The Major soils of the world. Koninklijke Wöhrmann B.V., Zutphen, The Netherlands. 310 pp.

Hernández-Moreno, J.M. \& M.A. Negrin. 1998. Phosphorus extraction by anion exchange membranes (AEM) in Andisols. Communications in Soil Science and Plant Analysis 29: 1771-1778.

Hens, M. 1999. Aqueous phase speciation of phosphorus in sandy soils. Ph.D. thesis, Katholieke Universiteit Leuven, Belgium. 
P availability in Chilean and Flemish forests: De Brouwere, K. ET AL.

KosaKa, J., C.H. Honda \& A. IZEKI. 1962. Transformation of humus in upland soils, Japan. Soil Science and Plant Nutrition. 8: 191-197.

Kwong, K.F. \& P.M. Huang. 1979. Surface reactivity of aluminium hydroxides precipitated in the presence of low weight organic acids. Soil Science Society of America Journal 43: 1107-1113.

McLaughlin, J.R., J.C. Ryden \& J.K. Syers. 1981. Sorption of inorganic phosphate by iron- and aluminium-containing components. Journal of Soil Science 32: 365-377

Mora, M.L. \& J. Canales. 1995. Interactions of humic substances with allophonic compounds. Communications in Soil Science and Plant Analysis 26: 2805-2817.

Negrin, M.A., S. GonZalez-Carcedo \& J.M. Hernández-
Moreno. 1995. P fractionation in sodium bicarbonate extracts of andic soils. Soil Biology and. Biochemistry 27: 761- 766

OtAni, T \& N. Ae. 1999. Extraction of organic phosphorus in andosols by various methods. Soil Science and Plant Nutrition 45: 151-161.

Rajan, S.S.S. \& R.L. Fox. 1975. Phosphate adsorption by soils: II. Reactions in tropical acid soils. Soil Science Society of America Proceedings 40: 5154.

Schwertman, U. 1973. Use of oxalate for Fe extraction from soil. Canadian Journal of Soil Science 53: 244-246.

Tiessen, H, J.W.B. Stewart \& C.V. Cole. 1984. Pathways of phosphorus transformations in soils of differing pedogenesis. Soil Science Society of America Journal 48: 853-858.

Received: $26 / 12 / 02$

Accepted: 09/04/03 